\title{
Inventorship and Authorship
}

\author{
Antoinette F. Konski and Linda X. Wu \\ Foley and Lardner LLP, Palo Alto, California 94304-1013 \\ Correspondence: akonski@foley.com; Iwu@foley.com
}

Ownership of a U.S. patent is based on inventorship. In the United States, an inventor is the owner of the claimed invention unless it is assigned to another entity. The correct naming of inventors is important, and the improper naming of inventors in a patent can be grounds for rendering the patent unenforceable. Each inventor must make an intellectual contribution, solely or jointly, to at least one element of a claim in the patent. This is in contrast to authorship of a research article, where authors may be named to acknowledge contribution to the reported research rather than an intellectual contribution. Thus, identifying inventors for a patent is not the same as identifying authors for a publication.

$T^{w}$ wo professors meet and design experiments to prove that knocking out a gene will treat a fatal neurodegenerative disease. One professor, a neurophysiologist and expert physician, has studied the disease and its symptoms, and conceived of the idea to treat the disease by knocking out the gene. However, she lacks the expertise to design and perform the experiments to actually knock out the gene. The other, an expert molecular biologist, has the expertise to knock out the gene but has never studied neurophysiology and has no expertise in treating the fatal neurodegenerative disease. The two design the experiments to show that knocking out the gene will treat the disease in an experimental animal model. In his laboratory, the molecular biologist and those working under his direction and supervision apply techniques well known in the field to knock out the gene selected by the neurophysiologist. A graduate student, studying under the molecular biologist, is assigned to the project. During the course of the project, there is trouble with the conventional techniques for knocking out the gene and the graduate student modifies the procedure, creating new techniques she independently developed. She begins corresponding directly with the physician-scientist. However, the techniques require reagents that are not commercially available. Another laboratory donates the materials. The initial proof of concept is successful, and two technicians are assigned to the project to complete the experiments, acting under the direction and supervision of the graduate student utilizing the procedures developed by the graduate student. A manuscript is prepared and submitted to a prestigious journal. The two professors, the graduate student, and the two technicians are named coauthors. A patent application was filed prior to submission of the manuscript. Who are the inventors of the patent application claiming the new method to knock out the gene and the

Editors: Salim Mamajiwalla and Rochelle Seide

Additional Perspectives on Intellectual Property in Molecular Medicine available at www.perspectivesinmedicine.org

Copyright (C) 2015 Cold Spring Harbor Laboratory Press; all rights reserved; doi: 10.1101/cshperspect.a020859

Cite this article as Cold Spring Harb Perspect Med 2015;5:a020859 
treatment of the neurological disorder? Should all the coauthors named on the manuscript be named as joint inventors?

Naming all coauthors on a journal article as joint inventors may be the less controversial means to determining inventorship of a patent claim because many in academia and industry are familiar with the requirements for authorship. In addition, acknowledging all who contributed to a project is encouraged. However, U.S. patent law does not equate authorship with inventorship.

U.S. patent law requires that only a person or persons who invent patentable subject matter be named as a sole or joint inventor of a claim in a pending application or issued patent. ${ }^{1}$ The difficult question is, especially when more than one individual is involved in designing or performing the experiments in the course of a project, who is an inventor? ${ }^{2}$

Inventorship is determined based on the "claimed invention" and must be determined on a claim-by-claim basis. Thus, the inventorship of the application or patent as a whole may change during examination of the application as the claims of a patent application are modified or dropped.

Thought and diligence should be used to understand each individual's contribution to the claims of the patent application and issued patent because the question of inventorship is an important one. Under U.S. law, inventors own all inventions claimed in a pending application or issued patent absent a contract or agreement to the contrary. In addition, each inventor owns an equal right in a patent application or patent and can therefore make, use, or sell the invention without permission of his coinventors. Incorrectly identifying inventors can be grounds to invalidate the patent (see Jamesbury Corp. v. United States (518 F.2d 1384, 1395) (Ct. Cl. 1975) ${ }^{3}$ and C.R. Bard, Inc. v. M3 Systems, Inc. (157 F.3d 1340, 1353) (Fed. Cir.

\footnotetext{
${ }^{1} 35$ U.S.C. $\$ \$ 101,111$, and 116.

${ }^{2} 35$ U.S.C. $\$ 116$

${ }^{3}$ Inclusion of more or less than the true inventors renders patent void and invalid.
}

1998)), ${ }^{4}$ and omitting an inventor can render a patent unenforceable (Frank's Casing Crew \& Rental Tools, Inc. v. PMR Technologies, Ltd. (292 F.3d 1363, 1376) (Fed. Cir. 2002)). Moreover, to bring a patent infringement action, all inventors must be included as plaintiffs, and if a court finds that an inventor has been omitted, the omitted inventor must join as a plaintiff for the litigation to proceed (Ethicon, Inc. v. U.S. Surgical Corp. (135 F.3d 1456, 1465-1466) (Fed. Cir. 1998)).

This work reviews the criteria for inventorship, and in particular joint inventorship, as well as several court decisions that have applied the criteria and concepts to various factual scenarios. It also touches on the distinction between inventorship and authorship. It reviews general concepts of inventorship, including a detailed discussion regarding "conception" and contributions that have and have not been determined to be inventive contributions to an invention. It also reviews the requirement for collaboration when more than one individual has been alleged to contribute to the invention.

\section{INVENTORSHIP_GENERAL CONCEPTS}

An inventor, under U.S. patent law, is "whoever invents or discovers any new and useful process, machine, manufacture, or composition of matter, or any new use and useful improvement thereof." Moreover, whoever so "invents or discovers" may obtain a patent, which expressly confers on the inventor of the patent an exclusive right to exclude others from making, selling, or offering to sell the patented invention in the United States and from importing the patented invention into the United States for a period of years.

Conception is considered to be the touchstone of inventorship, and where more than one individual contribute to an invention, each must

\footnotetext{
4"To invalidate a patent based on incorrect inventorship it must be shown not only that the inventorship was incorrect, but that correction is unavailable under section 256." ${ }^{5} 35$ U.S.C. $\$ 101$.
} 
Inventorship and Authorship

show contribution to its conception. ${ }^{6}$ Conception, in terms of inventorship, has been defined as:

the complete performance of the mental part of the inventive act. All that remains to be accomplished, in order to perfect the act or instrument, belongs to the department of construction, not invention. It is therefore the formation, in the mind of the inventor of a definite and permanent idea of the complete and operative invention, as it is therefore to be applied in practice, that constitutes an available conception, within the patent law (Coleman v. Dines (754 F.2d 353, 359) (Fed. Cir. 1985) (citing Gunter v. Stream (573 F.2d 77, 80) (C.C.P.A. 1978))).

The U.S. Court of Appeals for the Federal Circuit (CAFC) has stated that the test for conception is whether the inventor had an idea that was definite and permanent enough that one skilled in the art could understand the invention; the inventor must prove his conception by corroborating evidence, preferably by contemporaneous disclosures (Burroughs Wellcome Co. v. Barr Laboratories, Inc. (40 F.3d 1223, 1228) (Fed. Cir. 1994)). An inventor need not know that his invention will work for conception to be complete; he needs only show that he had the complete mental picture and could describe it with particularity. That the invention actually works is part of its reduction to practice. ${ }^{8}$ In a joint invention, each inventor must contribute to the joint arrival at a definite and permanent idea of the invention as it will be used in practice.

${ }^{6}$ Indeed, the U.S. patent statute expressly allows for more than one individual to invent and apply for a patent. 35 U.S.C. $\$ 116(\mathrm{a})$ recites:

When an invention is made by two or more persons jointly, they shall apply for patent jointly and each make the required oath, except as otherwise provided in this title. Inventors may apply for a patent jointly even though (1) they did not physically work together or at the same time, (2) each did not make the same type or amount of contribution, or (3) each did not make a contribution to the subject matter of every claim of the patent.

See also Ethicon (135 F.3d at 1460-1461) (citing Burroughs Wellcome Co. v. Barr Laboratories, Inc. (40 F.3d 1223, 12271228) (Fed. Cir. 1994)).

${ }^{7}$ Id.

${ }^{8}$ Id. at 1229.

\section{TIMING OF THE “INVENTIVE” CONTRIBUTION}

Inventive contribution is based on the timing and quality of the contribution to the conception of the claimed invention. Thus, determining whether or not an individual made an "inventive" contribution requires determining when the conception is "complete," which in turn requires evaluating the amount of experimentation necessary to reduce the invention to practice (proof of concept) and the amount of information necessary to distinguish the invention from the prior art. Those who join a research project after conception has been completed cannot be inventors.

For example, in the case of University of Pittsburgh v. Hedrick (573 F.3d 1290) (Fed. Cir. 2009), the U.S. Court of Appeals affirmed the decision of the trial court that Hedrick, Benhaim, Lorenz, and Zhu were not coinventors because their contribution to the research effort came after conception of the claimed invention was complete.

The lawsuit involved U.S. Patent No. $6,777,231$ (the '231 patent) directed to an adipose-derived stem cell that can differentiate into two or more of a bone cell, a cartilage cell, a nerve cell, or a muscle cell. Katz and Llull at the University of Pittsburgh initiated research related to the isolation, culturing, and passaging of stem cells isolated from human liposuctioned adipose tissue (adipose-derived stem cells). ${ }^{9}$ They hypothesized that these cells could differentiate into other cell types, including bone, cartilage, muscle, and nerve. Although not scientifically certain, Katz and Llull believed that they had observed adipose stem cells changing into cells resembling muscle and fat cells, and commented to another colleague via E-mail that they might have seen the cells transformed into nerve cells. Katz and Llull decided to substantiate what they had observed (i.e., that the cells indeed were nerve cells).

Thereafter, Hedrick joined the University of Pittsburgh laboratory for a yearlong fellowship. Around the same time, Katz submitted a grant

${ }^{9}$ Id. 
proposal summarizing his work with Llull, and Hedrick was not mentioned in the grant proposal. Hedrick, however, wrote his own research proposal setting forth some experiments on Katz's cells. A few months later, Katz, Llull, and Hedrick submitted an invention disclosure to the University of Pittsburgh stating that the isolated cells could be induced to transform into fat, bone, cartilage, and muscle tissues.

A few months later, Hedrick's fellowship ended, and he left for UCLA, where he formed a new laboratory with Benhaim, Lorenz, and Zhu. There the UCLA group worked on the same cells as the Pittsburgh group. The UCLA group determined that this adipose stem cell population was distinct from the prior art stem cell populations because they responded differently to induction media. In late 1999 and 2000, the UCLA group successfully cloned single, adipose-derived cells. Meanwhile, Katz and the Pittsburgh group continued to research the exploitable potential of his adipose-derived stem cells.

The Pittsburgh group and the UCLA group each filed patent applications to adipose-derived stem cell populations. The Pittsburgh application named Katz, Llull, Futrell, Hedrick, Benhaim, Lorenz, and Zhu as inventors. The application contained information from $\mathrm{He}$ drick regarding compositions and methods to induce the adipose-derived stem cells to differentiate into nerve cells. At the request of Hedrick, UCLA's patent application also included the concept that the adipose-derived stem cells could differentiate into nerve cells, although he had not conducted any nerve differentiation experiments. The Pittsburgh application was issued as the '231 patent.

In late 2009, the University of Pittsburgh filed a lawsuit seeking to remove Futrell, Hedrick, Benhaim, Lorenz, and Zhu as named coinventors. Futrell voluntarily dismissed himself from the lawsuit.

In agreeing with Pittsburgh that Hedrick, Benhaim, Lorenz, and Zhu should be removed as named coinventors, the district court determined that conception was complete prior to Hedrick's arrival at Pittsburgh and that Katz's notebooks enabled one to reproduce the differ- entiation of the adipose-derived stem cells into each of the lineages claimed in the ' 231 patent.

On appeal the U.S. CAFC agreed with the district court and noted that the fact that Katz and Llull were uncertain that the adipose-derived stem cells could actually differentiate into all claimed lineages was immaterial. The CAFC stated that "Proof that the invention works to a scientific certainty is reduction to practice ... it is immaterial that their knowledge was not scientifically certain and that the ... [UCLA] researchers helped them gain such scientific certainty." 10

\section{EXPERIMENTATION AND CONCEPTIONS}

As stated above, conception is the formation in the mind of the inventor of a definite and permanent idea of the complete and operative invention. For the conception to be complete, however, there must be a means to make and/ or use the invention. For inventions in predictable technologies that are therefore less complex to make or use, for example, a mechanical or medical device, all that may be required to complete the conception is a drawing of the device in a manner that distinguishes the invention from the prior art. When the invention is in an unpredictable technology, for example, in chemistry or biotechnology, conception may not be complete until the inventor or joint inventors are in possession of an operative method for making it (see Burroughs Wellcome (40 F.3d at 1229)).

If the invention can be made in accordance with conventional techniques, it is deemed to have been conceived when it was described, and the question of whether the conceiver is in possession of a means of making it is simply not raised (Oka v. Youssefyeh (849 F.2d 581, 583) (Fed. Cir. 1988)). Thus, in situations in which nothing more than routine skill is needed to show proof of concept or to reduce the invention to practice, the invention is complete simultaneously with the idea itself. For chemical compounds with straightforward chemical synthesis, conception is complete with a descrip-

${ }^{10} I d$. at 1299. 
tion of the structure of the compound, as nothing more is required to put the compound in the hands of the public (see Rey-Bellet v. Engelhardt (493 F.2d 1380, 1387) (C.C.P.A. 1974)). In such a situation, even subsequent routine testing and experimentation will not preclude a finding of conception at the time of mental formulation. ${ }^{11}$

In contrast, when the claimed invention cannot be made with conventional techniques, conception requires not only the idea of the invention but also possession of an operative method of making and/or using it. This factual scenario was addressed in the case of Oka v. Youssefyeh (849 F.2d at 583). In Oka the original date of conception was alleged to be February 27,1980 , the date when the inventors believed the compounds could be prepared in accordance with conventional techniques. However, a skilled chemist assigned to the project found that conventional methods were unsuccessful to synthesize the compounds. Indeed, it was not until the last week of October 1980 that the conception was complete, because it was only at that time that an operative method of making the compounds was known (see Oka (849 F.2d at 584); see also Alpert v. Slatin (305 F.2d 891, 894) (C.C.P.A. 1962)). ${ }^{12}$

Thus, in situations in which the invention cannot be made with conventional techniques, conception is not complete until it is actually reduced to practice.

In certain situations conception is not complete until the invention is actually reduced to practice or until proof of concept has been completed, such that it can be distinguished from the prior art. This scenario is known as the doctrine of simultaneous conception and reduction to practice. The doctrine has been particularly

\footnotetext{
${ }^{11}$ See $i d$. (wherein the court stated that subsequent testing and experimentation routinely done for drugs did not automatically bar a claim that the antidepressant was conceived prior to completion of testing and experimentation); see also Burroughs Wellcome (40 F.3d at 1230) (stating that conception does not require reduction to practice where no prolonged period of extensive research, experiment, and modification followed the alleged conception).

${ }^{12}$ The mental embodiment of the invention was a mere hope or expectation, a statement of a problem, but not an inventive conception, because additional experimentation was necessary for enablement.
}

applicable to the field of biological materials because an inventor is often unable to envision the detailed constitution of a compound so as to distinguish it from other materials, as well as a method for obtaining it, such that conception is not achieved until reduction to practice has occurred, that is, until after the compound has been isolated.

Conception of isolated genes had been adjudicated to be complete when the complete sequence of the gene was determined because the sequence of the gene is required before it can be distinguished from the prior art (Amgen, Inc. v. Chugai Pharmaceutical Co., Ltd. (927 F.2d 1200, 1206) (Fed. Cir. 1991)). It was explained that:

a product is not conceived until one can define it other than by its biological activity or function. ${ }^{13}$ The difficulty that would arise if we were to hold that a conception occurs when one has only the idea of a compound, defining it by its hoped-for function, is that would-be inventors would file the patent applications before they had made their inventions and before they could describe them. That is not consistent with the statute or the policy behind the statute, which is to promote disclosure of inventions, not of research plans. While one does not need to have carried out one's invention before filing a patent application, one does need to be able to describe that invention with particularity (Fiers $v$. Revel (984 F.2d 1164, 1169) (Fed. Cir. 1193)).

However, that is not to say that an invention to a gene cannot be complete if other methods are available to distinguish it from the prior art. In Sanofi-Aventis v. Pfizer, Inc. (733 F.3d 1364) (Fed. Cir. 2013), the CAFC affirmed the U.S. Patent Office's (USPTO) determination that an invention was complete when Pfizer isolated the complementary DNA (cDNA) sequence even though the initial sequence contained errors because Pfizer could define the cDNA so as to distinguish it from other materials and define how to obtain it.

\footnotetext{
${ }^{13}$ Although the court loosely used the term "biological activity or function," the product under consideration by the court was a gene or nucleic acid sequence. An actual reduction to practice had not yet taken place, and a biological deposit of the gene was not made in support of enablement.
} 


\section{QUALITY OF CONTRIBUTION}

In addition to evaluating when conception has been completed, the quality of the contribution of a putative invention must be evaluated. The inventive contribution of each inventor need not be of the same kind or degree, but must in some manner relate to at least one claim (Ethicon, Inc. v. U.S. Surgical Corp. (135 F.3d 1456, 1460-1461) (Fed. Cir. 1998)).

One court noted that:

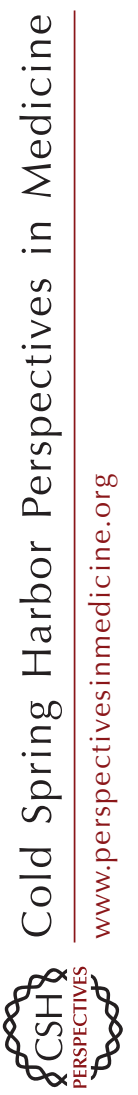

[a]ll that is required of a joint inventor is that he or she (1) contribute in some significant manner to the conception or reduction to practice of the invention, (2) make a contribution to the claimed invention that is not insignificant in quality, when that contribution is measured against the dimension of the full invention, and (3) do more than merely explain to the real inventors well-known concepts and/or the current state of the art" (Pannu v. Iolab Corp. (155 F.3d 1344, 1351) (Fed. Cir. 1998)).

It is not necessary that "the entire inventive concept should occur to each of the joint inventors," so long as each inventor "makes some original contribution, though partial, to the final solution of the problem" (Kimberly-Clark Corp. v. Procter \& Gamble Distributing Co. (973 F.2d 911, 916-917) (Fed. Cir. 1992)). Each joint inventor must have contributed to the conception of that invention in a way not obvious to one ordinarily skilled in the art (AcroMed Corp. v. Sofamor Danek Group, Inc. (253 F.3d 1371, 1379-1380) (Fed. Cir. 2001)).

Inventorship requires a contribution from each inventor that is not insignificant in quality when that contribution is measured against the dimensions of the full invention (Рапnи (155 F.3d at 1351)). The contribution of each inventor need not be the same type or amount, nor must each inventor make a contribution to every claim of a patent (Ethicon (135 F.3d at 1460-1465)). ${ }^{14}$ Additionally, "[o]ne [inventor] may do more of the experimental work while

\footnotetext{
${ }^{14}$ Individual was joint inventor, even though he only contributed to one element each of two claims of the 55 total claims that were issued.
}

the other makes suggestions from time to time" (Monsanto Co. v. Kamp (269 F. Supp. 818, 824) (D.D.C. 1967)).

Determining what constitutes "not insignificant" is subjective and fact-specific. The courts have required more than merely suggesting an idea of a result, providing services or ideas, or aiding in perfecting an already fully conceived invention (Eli Lilly \& Co. v. Aradigm Corp. (376 F.3d 1352, 1363) (Fed. Cir. 2004)). It is important to note, however, that a person is not "precluded from being a joint inventor simply because his [or her] contribution to a collaborative effort is experimental" (Burroughs Wellcome (40 F.3d at 1229)).

One who suggests an idea of a result sought, but not the means of accomplishing it, does not qualify as an inventor (Eli Lilly \& Co. v. Aradigm Corp. (376 F.3d 1352, 1359) (Fed. Cir. 2004), citing Garrett Corp. v. United States (422 F.2d 874, 881) (Ct. Cl. 1970); see also Ex Parte Smernoff (215 U.S.P.Q. 545, 547) (B.P.A.I. 1982)). Thus, courts have not recognized inventorship status for those who suggest some way to improve an invention casually but take no further role in working on the invention. ${ }^{15}$ Similarly, "[a]n inventor 'may use the services, ideas, and aid of others in the process of perfecting his invention without losing his right to a patent" (Shatterproof Glass Corp. v. Libbey-Owens Ford Co. (758 F.2d 613, 624) (Fed. Cir. 1985), quoting Hobbs v. U.S. Atomic Energy Commission (451 F.2d 849, 864) (5th Cir. 1971)). In addition, a joint inventor must do more than merely explain to the real inventors well-known concepts and/or the current state of the art (Pannu (155 F.3d at 1351); see also

\footnotetext{
${ }^{15}$ See Mueller Brass Co. v. Reading Industries, Inc. (352 F. Supp. 1357, 1373) (E.D. Pa. 1972) (affirmed without opinion, 487 F.2d 1395) (3rd Cir. 1973) (district court denied coinventorship status to "a person who suggests some way to improve an invention casually but takes no further role in fitting the rough suggestion into the scheme of the invention workably"); Pro-Mold \& Tool Co., Inc. v. Great Lakes Plastics, Inc. (75 F.3d 1568, 1575-1576) (Fed. Cir. 1996) (finding of no inequitable conduct for failure to disclose a coinventor because alleged coinventor merely planted seeds for the idea but did no work on creating invention).
} 
Hess v. Advanced Cardiovascular Systems, Inc. (106 F.3d 976, 981) (Fed. Cir. 1997)). ${ }^{16}$

For example, in the case of Hess v. Advanced Cardiovascular Systems, Inc. (106 F.3d 976) (Fed. Cir. 1997), Hess, an expert in materials science, was determined not to be an inventor because his contribution was only providing information well known and found in textbooks. The invention related to a balloon angioplasty catheter. The catheter initially was conceived by two doctors but required a different material for the catheter. The doctors were referred to Hess because his company was one of the largest manufacturers of heat-shrinkable material. After the doctors consulted with Hess, he suggested specific tubing made by his company and explained how it worked and might be used for the catheter. By using the tubing suggested by Hess, the doctors developed and patented the successful balloon angioplasty catheter.

The court determined that Hess was not entitled to be named as a joint inventor of the catheter because the two doctors performed extensive research and development work that produced the catheter. Hess's contribution was well known and "did no more than a skilled salesman would do in explaining how his employer's product could be used to meet a customer's requirements." ${ }^{17}$ The court, in reaching this conclusion, quoted an 1853 Supreme Court decision involving Samuel Morse's invention of the telegraph. The Supreme Court determined that only Morse was the inventor even though he consulted with others during the development of the invention. It was explained that

[n]o invention can possibly be made, consisting of a combination of different elements ... without a thorough knowledge of the properties of each of them, and the mode in which they operate on each other. And it can make no difference,

\footnotetext{
${ }^{16}$ Plaintiff did no more than supply state-of-the-art products and explain well-known principles that could be found in textbooks; see also Board of Education v. American Bioscience, Inc. (333 F.3d 1330, 1341) (Fed. Cir. 2003) ("It is a longstanding principle of patent law that one who simply provides the inventor with well-known principles or explains the state of the art without ever having a firm and definite idea of the claimed combination as a whole does not qualify as a joint inventor.").

${ }^{17} I d$. at 981 .
}

in this respect, whether he derives his information from books, or from conversation with men skilled in the science. If it were otherwise, no patent, in which a combination of different elements is used, could ever be obtained (O'Reilly v. Morse (56 U.S. 62, 111) (1853)).

Although there is no exact test to determine what contribution would qualify as an inventive contribution, one legal commentator (Chisum 2008) has compiled a list of contributions that the courts have found to be insufficient to satisfy inventorship:

- suggesting a desired end or result, with no suggestion of means (see Cohen 2013);

- only following the instructions of the person or persons who conceive the solution to the problem; ${ }^{18}$

- acting to reduce to practice or demonstrate the efficacy of an already completely conceived invention; ${ }^{19}$

- only providing general information on design elements or the state of the art, with no knowledge of the ultimate goal or idea. ${ }^{20}$

In sum, inventorship requires each inventor to make a contribution to the conception of the invention that is collaborative, novel, nonobvious, sufficiently significant in quality, and not merely an explanation of the current state of the art or a reduction to practice of an already fully conceived invention. However, that contribution may be minimal, that is, only to an element of a single claim.

Consider the case of Ethicon, Inc. v. U.S. Surgical Corp. (135 F.3d 1456) (Fed. Cir. 1998), in which a technician who assisted with a project was named as a coinventor of a patent based on his contribution to portions of two claims of the patent.

In the late 1970 s Dr. Yoon, a medical doctor and prior inventor, conceived of a new endoscopic device that would prevent accidental injury during use. The device also would advise the surgeon

\footnotetext{
${ }^{18} I d$. at 393 n.77.

${ }^{19} \mathrm{Id}$. at $393 \mathrm{n} .78$.

${ }^{20}$ Id. at 393 n.79.
} 
when the surgical incision was complete. In 1980 Yoon met Mr. Choi, an electronics technician, who had some college training but no college degree. Yoon asked Choi to assist him with several projects, one of which was the improved endoscopic device. In 1982, after collaborating for $\sim 18$ months, their relationship ended. Choi thought that Yoon found his work unsatisfactory and withdrew from working with Yoon.

In the same year Yoon filed a patent application on the device. Without informing Choi, Yoon named himself as the sole inventor. In 1985 the USPTO granted the application, and U.S. Patent No. 4,535,773 (the '773 patent) was issued.

Yoon exclusively licensed the '773 patent to Ethicon, Inc., and sometime later, Yoon and Ethicon sued U.S. Surgical Corp. for infringement of the ' 773 patent. During the course of the lawsuit, U.S. Surgical contacted Choi regarding his involvement with the patented device. After Choi confirmed his role in the development of the patented device, U.S. Surgical obtained a retroactive license from Choi and moved to add Choi as an inventor on the '773 patent.

The trial court determined, and the CAFC affirmed, that Choi was a joint inventor with Yoon of the '773 patent because he contributed to at least one part of two claims of the patent, noting that "a co-inventor need not make a contribution to every claim of a patent." ${ }^{21}$ The lawsuit was dismissed because the original defendant, U.S. Surgical Corp., was licensed to use the patent by the license granted from Choi. Therefore, they could not infringe a patent that they were authorized by license to use.

This case illustrates that an inventor needs only contribute to the conception of a part of at least one claim of a patent and that credentials do not dictate whether or not an individual is or is not an inventor.

\section{COLLABORATION}

It is not uncommon for researchers in academic institutions to move among laboratories and apply skills and knowledge acquired in one laboratory to another. However, individuals alleging inventorship must establish that they collaborated during conception.

In the context of inventorship, what activities are considered to be qualitative collaboration? The U.S. courts have stated that the inventors need not work together at all times of a project, but they must at least be connected in some way to the project (Kimberly-Clark Corp. v. Procter \& Gamble Distributing Co. (973 F. 2d 911, 917) (Fed. Cir. 1992)). There must also be some connection between or among the joint inventors (Eli Lilly \& Co. v. Aradigm Corp. (376 F.3d 1352, 1362) (Fed. Cir. 2004)).

The issue of collaboration was addressed in the case of Huang v. California Institute of Technology (705 F. Supp. 2d 692) (E.D. Tex. 2010), wherein the court held that Huang was not an inventor because he could not establish that he collaborated with the named inventors.

Nevertheless, give-and-take interactions between joint inventors are not required. In $I P$ Innovation v. Red Hat, Inc. (9705 F. Supp. $2 \mathrm{~d}$ 692) (E.D. Tex. 2010), three inventors working for the same employer were named on a patent, but the alleged evidence showed that only two had developed the claimed invention. The court denied summary judgment for invalidity for incorrect inventorship because an article showed that the two later inventors knew of the earlier inventor's work at the company and may have built their invention upon the earlier work. ${ }^{22}$

The courts differ, however, on whether an alleged coinventor must communicate with the named inventors or if collaboration with someone connected to the named inventors can be sufficient.

In Ultra-Precision Manufacturing, Ltd. v. Ford Motor Co. (411 F.3d 1369) (Fed. Cir. 2005), the court denied joint inventorship where the evidence showed that there was no interaction between the plaintiffs and the named inventors during the time of the invention. The plaintiffs alleged that they had communicated

\footnotetext{
${ }^{21} I d$. at 1460 .
}

${ }^{22} I d$. 
with another Ford employee, but not the named inventors. The court held that even if the plaintiffs' work were considered a prior conception of the invention, they were not part of the collaborative efforts of the named inventors who engaged in the subsequent modifications and processes to arrive at the final invention. ${ }^{23}$

Similarly, in Arbitron, Inc. v. Kiefl (No. 09cv-04013 (PAC), 2010 U.S. Dist. LEXIS 83597 (S.D.N.Y. Aug. 13, 2010)), the court dismissed declaratory judgment with the defendant's claim for joint inventorship for lacking of collaboration because he did not interact with the named inventor. He only alleged that he previously had an open line of communication with the patentee's counsel, but did not offer factual allegations of a common inventive goal shared with the named inventor. ${ }^{24}$

On the other hand, in Memry Corp. v. Kentucky Oil Technology (No. C-04-03843 RMW, 2007 U.S. Dist. LEXIS 73315 (N.D. Cal. Sept. 20, 2007)), the court held that collaboration may be satisfied where evidence showed the alleged inventor had disclosed inventive concepts to a third party, who then communicated and collaborated with the named inventors. The court held that the evidence suggested that it was possible that the alleged inventor had collaborated in the inventive contributions provided by the third party, thus precluding summary judgment seeking to dismiss the correction of inventorship claim. ${ }^{25}$

In Rubin v. General Hospital Corp. (No. 0910040-DJC, 2011 U.S. Dist. LEXIS 45859 (D. Mass. Apr. 28, 2011)), coinventorship was denied where it was established that the groups had not worked together. Back in 2000 Dr. Rubin and his team identified an IKAP gene mutation as causing a syndrome known as familial dysautonomia. Rubin sent his article to the American Journal of Human Genetics, which forwarded the abstract to Dr. Gusella at Massachusetts General Hospital for peer review. Gusella then filed a provisional patent application

${ }^{23} I d$.
${ }^{24} I d$.
${ }^{25} I d$. in January 2001, shortly before Rubin's article was published. Gusella's team had been working on the same genetic problem as Rubin, which was why Rubin's article had been sent to him for peer review. Rubin had particularly requested the journal not to send it to Gusella because of the lab-lab competition, but the journal sent it anyway.

After Gusella's patent issued, Rubin sued under 35 U.S.C. $\$ 256$, asking the court to add him as a joint inventor. The district court dismissed the case because there was no evidence of collaboration between Rubin and Gusella, as required for joint inventorship. ${ }^{26}$

On appeal the CAFC affirmed the district court's decision. The CAFC stated that "the independent relationship between these teams of scientists, and the nature of this communication of information, do not support joint invention in accordance with $\$ 116$, or warrant change or substitution of inventorship under $\$ 256$ ” (Anderson v. General Hospital Corp., No. 20111439, 2013 U.S. App. LEXIS 6157, at *10 (Fed. Cir. Mar. 28, 2013)).

\section{CORROBORATION}

Those who allege inventorship must validate their contribution by corroborating evidence. Corroboration ensures that the inventor actually prepared and knew that the invention would work. The purpose of requiring corroboration is to prevent fraud (Sandt Technology, Ltd. v. Resco Metal \& Plastics Corp. (264 F.3d 1344, 1350) (Fed. Cir. 2001)). The corroborating evidence must meet the particular party's burden of proof and must show that the inventor disclosed his "complete thought expressed in such clear terms as to enable those skilled in the art to make the invention" (Coleman v. Dines (754 F.2d 353, 359) (Fed. Cir. 1985), quoting Field v. Knowles (183 F.2d 593, 601) (C.C.P.A. 1950)).

To establish joint inventorship, each "purported inventor must provide corroborating evidence of any asserted contribution to the conception" (AcroMed Corp. v. Sofamor Danek

${ }^{26} I d$. 
Group, Inc. (253 F. 3d 1371, 1379) (Fed. Cir. 2001), citing Fina Oil \& Chemical Co. v. Ewen (123 F.3d 1466, 1474) (Fed. Cir. 1997)). The testimony of joint inventors is insufficient to establish independent corroboration (Andersen v. Piepper (442 F.2d 982) (C.C.P.A. 1971)). Both conception and reduction to practice must be corroborated by evidence other than given by joint applicants (Manny v. Garlick (135 F.2d 757, 773) (C.C.P.A. 1943)). Such evidence must be "clear and convincing" (Eli Lilly (376 F.3d at 1364-1365)).

A "rule of reason" analysis is applied to determine corroboration (Price v. Symsek (988 F.2d 1187, 1195) (Fed. Cir. 1993)). Under this analysis an evaluation of all pertinent evidence must be made. ${ }^{27}$ Corroborating evidence may take many forms. Typically, an inventor's testimony or unwitnessed notebook alone will be insufficient to corroborate inventive contribution (see Mikus v. Wachtel (542 F.2d 1157) (C.C.P.A. 1976) ${ }^{28}$ and Price (988 F.2d at 1194) (Fed. Cir. 1993)). ${ }^{29}$ Documentary or physical evidence that is made contemporaneously with the inventive process is the most reliable (Woodland Trust v. Flowertree Nursery, Inc. (148 F.3d 1368, 1373) (Fed. Cir. 1998)). However, circumstantial evidence about the inventive process may also corroborate, especially when the circumstantial evidence is of an independent nature (see In re Jolley (308 F.3d 1317, 1325) (Fed. Cir. 2002) and Trovan, Ltd. v. Sokymat SA (299 F.3d 1292, 1303) (Fed. Cir. 2002)). Oral testimony by someone other than the alleged inventor may also serve as corroboration (Jolley (308 F.3d at 1325); see also Trovan (299 F.3d at 1303)).

\section{THE DIFFERENCE BETWEEN INVENTORSHIP AND AUTHORSHIP}

As a result, an inventor must contribute to the conception of an invention, and an individual

\footnotetext{
${ }^{27} I d$.

${ }^{28}$ Inventor's unwitnessed notebook was insufficient corroboration.

${ }^{29}$ An inventor's testimony, standing alone, is insufficient to prove conception.
}

who only contributes concepts or techniques well known in the art is not, under the law, an inventor. Thus, identifying an inventorship for a patent is not the same as identifying authorship for a publication. It is important not to confuse authorship with inventorship.

It is common that a scientific publication names many coauthors, including the principal investigator, graduate students, postdoctoral fellows, technicians, collaborators, and their staff members who are involved in performing the experiments and/or providing materials and equipment. As such, the authorship of a publication can be based on various factors, one of which may be an individual's contribution to the data produced in the publication or reduction to practice of the inventive ideas in the publication.

In contrast, the inventorship of a patent is strictly construed based on the conception of the inventive subject matter. A person who merely reduces the conception of an invention to practice by exercising ordinary skill in the art, such as a graduate student or technician working under the direction and supervision of a professor in contributing data included in the patent application, is not an inventor. A person who contributes to an element to the invention that is known to a person of ordinary skill in the art is not an inventor. A person who provides mere technical support is not an inventor. A person who provides suggestions or improvements that are well known and can be found in the textbooks is not an inventor. A person who merely suggests an idea of a result to be accomplished, rather than means of accomplishing it, is not an inventor.

Authorship and inventorship differ in two additional, important aspects. There is no requirement that the authors work together or collaborate for authorship, and there is no requirement similar to corroboration of contribution for authorship of a publication.

The USPTO recognizes that coauthors are not necessarily inventors. For example, an inventor's prior publication could have been raised as prior art during the examination of the patent if the publication names additional individuals who are not named as inventors 
of the application. If the article was published $<1$ year from the effective filing date of the claim, prior art effect of the publication can be removed by a showing that the authors not named as inventors did not contribute to the rejected claims. This is accomplished by the inventors filing a paper attesting that the authors not named as inventors were correctly not named; for example, they were acting under the direction and supervision of one or more inventors. This is the situation that was addressed in In re Katz (687 F.2d 450) (C.C.P.A. 1982). An article, alleged to fully describe a claimed invention by Dr. Katz, was published 8 months prior to his filing of a patent application. The article listed three coauthors, Katz and his two students. During the prosecution of Katz's patent application, the USPTO cited the article as a prior art reference negating patentability of the patent application. Katz filed a declaration declaring that he was the sole inventor of the subject matter described and claimed in the application. In his declaration Katz stated that the other two authors were students working under his direction and supervision and that they were not coinventors, even though they were coauthors of the article. The court held that authorship of an article by itself did not "raise a presumption of inventorship with respect to the subject matter disclosed in the article" (In re Katz (687 F.2d at 455)). By establishing that the unnamed authors were not inventors, the publication was shown to be the inventor's own publication and therefore not disqualifying prior art.

\section{INVENTORSHIP OF THE KNOCKOUT GENE INVENTION}

With knowledge of the standards of inventorship, who is an inventor of the method to treat the fatal neurodegenerative disease by knocking out the gene, as described at the beginning of this review? To determine inventorship, it is important to establish when the conception of the invention was complete. Was conception of the invention complete prior to the engagement of the molecular biologist, or was it complete after the development of new techniques for knock- ing out the gene? Or yet further, was conception complete only after the animal model was created and the proof of concept completed with the reagents donated by another laboratory?

The preceding case law suggests that if the invention was not predictable and could not be made with conventional techniques, conception may not be complete until an operative method of making the invention was known. For that reason it is likely that conception under the above facts was not complete until the method of making the knockout model was completed.

Thus, any individual who was actively engaged in the project is a putative inventor: the neurophysiologist and expert physician who conceived of the idea to treat the disease by knocking out the gene; the molecular biologist; the graduate student studying under the molecular biologist; the two technicians assigned to the project; and individuals from the laboratory who created the reagents that were necessary to establish proof of concept. The question then becomes, who in the group made an inventive contribution? Without doubt, the physician who originally conceived of the method to treat the disease and the proof of concept is an inventor. Provided that the molecular biologist contributed in a manner that was beyond the knowledge of one of skill in the art, he could be a joint inventor. However, the facts suggest that he only provided textbook knowledge and therefore his contribution likely did not rise to the level of inventorship.

Is the graduate student who created techniques to knock out the gene an inventor? The facts suggest that the invention was not complete without this contribution, and the facts establish that the physician-scientist and the graduate student directly collaborated during the project. Thus, it is likely that the graduate student would be an inventor because her contribution was necessary to complete conception and was beyond the contribution of ordinary skill.

There are no facts establishing that the technicians or donating laboratory provided any contribution to the conception. Although the materials and skill donated by them were necessary to complete conception, they did no more than "ordinary skill." 
Contrast the inventorship analysis with conventional authorship, which would likely name the inventor-scientist, the molecular biologist and his graduate student, and individuals who may have contributed the materials to carry out the proof-of-concept experiments. In some instances, one or both technicians would have been named as well. Using an authorship analysis to determine inventorship would have expanded the list of inventors to include those who did not collaborate with the physician-inventor and only contributed conventional skill in the art.

\section{A NOTE ABOUT THE AMERICA INVENTS ACT}

In 2011 the Leahy-Smith America Invents Act $(\text { AIA })^{30}$ was enacted, which modified many of the procedures that are used to procure a patent in the USPTO. One significant change is that the United States has transitioned from a "first to invent" system to a "first inventor to file" system. ${ }^{31}$ Prior to the AIA, a person(s) who first conceived an invention and reduced it to practice or was first to conceive the invention and diligent in reducing it to practice was considered to be the inventor or joint inventor. In contrast, under the AIA, the person(s) who is first to file an application on an invention is considered to be the inventor or joint inventor, even if another person(s) invented it prior to the first filer. ${ }^{32}$

Although the AIA introduced significant changes to U.S. patent law, the core concepts regarding inventorship remain unchanged. It is said that the inventorship remains to be determined almost exclusively based on the conception of the inventive subject matter claimed. As seen above, the courts have defined the term "conception" to mean "the formation in the mind of the inventor, of a definite and permanent idea of the complete and operative inven-

\footnotetext{
${ }^{30}$ Leahy-Smith America Invents Act, Pub. L. No. 112-29 (2011).

${ }^{31} \mathrm{Id}$.

${ }^{32} I d$. There are provisions under the AIA to grant a patent to the second patent filer, such as when the first patent filer derived the invention from a subsequent patent filer. However, these concepts are beyond the scope of this review (see, e.g., Konski 2013).
}

tion, as it is thereafter to be applied in practice" (Burroughs Wellcome Co. v. Barr Laboratories, Inc. (40 F.3d 1223, 1228) (Fed. Cir. 1994)). In other words, if a person of ordinary skill in the art (e.g., a professor) can reduce the invention to practice without undue experimentation, then the conception is complete and the person who conceived the subject matter is the inventor.

\section{CORRECTING INVENTORSHIP}

Inventorship may be corrected in a pending patent application and even an issued patent if the mistake in inventorship is not made with any deceptive intent. On the other hand, a patent is invalid if the mistake is made with deceptive intent, which is defined as a fraudulent or deliberate act of an inventor or applicant for reasons unrelated to the considerations of inventorship to name a noninventor as an inventor on a patent or patent application. Deceptive conduct is inequitable and actionable, which can render a patent unenforceable.

In Frank's Casing Crew \& Rental Tools, Inc.v. PMR Technologies, Ltd. (292 F.3d 1363) (Fed. Cir. 2002), two individuals who did not actually invent the claimed invention applied for a patent application. They named themselves as inventors and concealed the true inventor's identity from the USPTO. Although the true inventor subsequently established the true and correct inventorship, the patent was unenforceable because the error in inventorship was made with deceptive intent by those who applied for the patent application. The court held that the true inventor could not enforce the patent even if he was innocent and had no deceptive intent on his part. ${ }^{33}$

If the error in naming inventors is made without deceptive intent, the courts have held that incorrect inventorship should be easily cured because it is often a technical defect. There are many types of incorrect inventorship; for example, no true inventor is named, or some but not all true inventors are named, or some noninventors are named as inventors, or a mix-

\footnotetext{
${ }^{33} I d$.
} 
Inventorship and Authorship

ture of a few true inventors and noninventors are named as inventors while some other true inventors are not named. Incorrect inventorship can also result during patent prosecution, when claims are added, amended, and/or cancelled because inventorship is determined on a claim-by-claim basis. For example, if an inventor contributes to one claim, which is cancelled during examination of the application, then he can no long be an inventor, and the inventorship should be amended to reflect the change.

Correcting inventorship during prosecution when the patent application is still pending is made by filing a petition with the USPTO, and therefore is less complex and costly than after the patent issues. For that reason, investigating inventorship prior to the filing of a patent application and monitoring it during examination and pendency of the application is the most prudent course to follow.

\section{REFERENCES}

Chisum D. 2008. Chisum on patents, \$2.02. Matthew Bender, New York.

Cohen ER. 2013. Clear as mud: An empirical analysis of the developing law of joint inventorship in the Federal Circuit. Berkeley Tech Law J 28: 383-416. http://scholarship .law.berkeley.edu/btlj/vol28/iss4/4.

Konski AF. 2013. Derivation and derivation proceedings. In America Invents Act: Law \& analysis (ed. Baluch AS, et al.), \$3. Aspen Publishers, New York. 


\section{$\&_{\mathrm{CSH}}^{\infty} \&$ Cold Spring Harbor

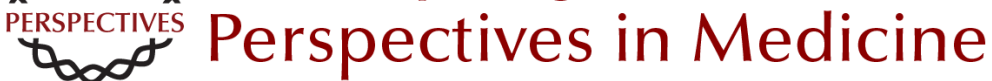

\section{Inventorship and Authorship}

Antoinette F. Konski and Linda X. Wu

Cold Spring Harb Perspect Med 2015; doi: 10.1101/cshperspect.a020859 originally published online August 7, 2015

\section{Subject Collection Intellectual Property in Molecular Medicine}

Patentability of Stem Cells in the United States Sarah E. Fendrick and Donald L. Zuhn, Jr.

Inventorship and Authorship Antoinette F. Konski and Linda X. Wu

The Patentability of Stem Cells in Australia Jenny Petering and Prue Cowin

Impact of America Invents Act on Biotech Intellectual Property

Amanda Murphy, Michael Stramiello, Jonathan Stroud, et al.

Introduction to Intellectual Property: A U.S.

Perspective

Amanda Murphy, Michael Stramiello, Stacy Lewis, et al.

The Role of Regulatory Agencies and Intellectual Property: Part I

Kevin E. Noonan

Canada's Patented Medicines (Notice of Compliance) Proceedings and Intellectual

Property

Henry Bian and Conor McCourt

Patentability of Genes: A European Union

Perspective

Paul Cole
The Impact of Myriad on the Future Development and Commercialization of DNA-Based Therapies and Diagnostics

Michele Wales and Eddie Cartier

Protecting Traditional Knowledge Related to

Biological Resources: Is Scientific Research

Going to Become More Bureaucratized?

Prashant Reddy and Malathi Lakshmikumaran

Protecting Trade Secrets in Canada

Noel Courage and Janice Calzavara

Inherent Anticipation in the Pharmaceutical and

Biotechnology Industries

Michael Goldman, Georgia Evans and Andrew Zappia

The Role of Regulatory Agencies and Intellectual

Property: Part II

Kevin E. Noonan

Baseball Bats and Chocolate Chip Cookies: The Judicial Treatment of DNA in the Myriad Genetics Litigation lan Binnie and Vanessa Park-Thompson

The Impact of Myriad and Mayo: Will

Advancements in the Biological Sciences $\mathrm{Be}$

Spurred or Disincentivized? (Or Was Biotech

Patenting Not Complicated Enough?) Jennifer Gordon

Trade Secrets in Life Science and Pharmaceutical Companies

Tara Nealey, Ronald M. Daignault and Yu Cai

For additional articles in this collection, see http://perspectivesinmedicine.cshlp.org/cgi/collection/ 